\title{
A KÉPALKOTÁS SZEREPE AZ IKERKUTATÁSOKBAN
}

\section{THE ROLE OF IMAGING IN TWIN RESEARCH}

\author{
Tárnoki Ádám Domonkos ${ }^{1}$, Tárnoki Dávid László2 \\ 1PhD, Dr. habil., Semmelweis Egyetem Radiológiai Klinika, tarnoki2@gmail.com \\ ${ }^{2} \mathrm{PhD}$, Dr. habil., Semmelweis Egyetem Radiológiai Klinika
}

\begin{abstract}
ÖSSZEFOGLALÁS
A képalkotó technológia az elmúlt évtizedben gyors fejlődésnek indult, melynek segítségével a radiológiai fenotípusok egyre pontosabb és átfogóbb vizsgálatára van lehetőség. A csaknem azonos genetikai állományú egypetéjű ikrek vizsgálata - különösen, ha egyikőjük krónikus betegségben szenved - segíthet megérteni, hogy a genetikai és környezeti (beleértve a bél mikrobiomot) hatások hogyan járulnak hozzá a komplex betegségek kialakulásához és radiológiai megjelenésükhöz. A képalkotás és az epigenetikai információ ötvözése képes arra, hogy megválaszolja azokat a kérdéseket, hogy a különböző képalkotó fenotípusok összefügghetnek, és akár előre jelezhetik az epigenetikai módosításokat, amelyek összefüggnek a szervek (például az agy) szerkezetével, működésével és anyagcseréjével, ami befolyásolja a betegség kialakulásának kockázatát és a progresszióját. A képalkotó módszerek epigenetikai markerekkel való integrálása, avagy a képalkotó epigenetika ígéretesnek tűnik. Az egyik legfontosabb epigenetikai markert, a bél mikrobiomot számos betegség kialakulásával összefüggésbe hozták. Az ikervizsgálatok lehetővé teszik a gazdaszervezet genetikai tulajdonságai és a bél mikrobiom sokfélesége közötti kapcsolat kutatását különböző betegségek terén, ami új biomarkerek és terápiás lehetőségek felfedezéséhez vezethet. Mindezen vizsgálatokhoz szükséges egy széles körű, nagy méretű, populációalapú hazai ikerregiszter, amely a Semmelweis Egyetemen létesül.
\end{abstract}

\section{ABSTRACT}

Imaging technology has developed rapidly over the past decade, enabling more precise and comprehensive examination of radiological phenotypes. Examination of monozygotic twins with almost identical genome, especially if one of them suffers from a chronic disease, can help to understand how genes and the environment (including gut microbiome) contribute to the development and radiologic appearance of complex diseases. Combination of epigenetics with imaging can answer questions whether various imaging phenotypes can predict epigenetic modification, that are related to organ (such as brain) structure, function and metabolism, which impacts disease risk and progression. Integration of imaging methods with epigenetic markers, i.e. imaging epigenetics, seems promising. One of the most important epigenetic markers, the gut microbiome has been associated with a variety of diseases. Twin studies allow the assessment of the relationship between host genetic variation and the diversity of gut microbiomes in various diseases, leading to the discovery of new biomarkers and therapeutic approaches. All these studies require a large, comprehensive population-based twin registry, which will operate in Semmelweis University in Hungary soon. 
Kulcsszavak: ikervizsgálat, képalkotás, ultrahang, radiogenomika, mély tanulás, mesterséges intelligencia, epigenetika

Keywords: twin research, imaging, ultrasound, radiogenomics, deep learning, artificial intelligence, epigenetics

\section{BEVEZETÉS}

Az ikervizsgálatok szerepet játszanak egy betegség vagy tulajdonság létrejöttéhez hozzájáruló genetikai és környezeti tényezők arányának meghatározásában, valamint a molekuláris genetikai és gén-környezet interakciós vizsgálatokban, továbbá fontos szerepük van annak felmérésében, hogy az életmódbeli, epigenetikai tényezők milyen befolyással bírnak a génjeink aktivitásának megváltoztatásában. Ahhoz, hogy megfelelő tudás birtokába jussunk bizonyos betegségek kialakulásával, pontosabb diagnosztikájával és perszonalizált kezelésével kapcsolatosan, elengedhetetlen több szempontból is tanulmányozni, vajon a gének és a környezet milyen módon befolyásolják azokat. A különbözőképpen megjelenő, radiológiai módszerekkel vizsgálható betegségeket, ún. képalkotó fenotípusokat egy genetikailag csaknem teljesen megegyező egypetéjü ikertestvérpárban is tudjuk vizsgálni, föként, ha csak egyikőjük szenved az illető betegségben, ami genomjuk, epigenomjuk vagy mikrobiomjuk különbözőségéből adódhat. Az ikervizsgálatok a tudomány számára egyedülálló mintát biztosítanak e tekintetben, s a populációszintủ ikerregiszter kialakítása ilyen genetikai és epigenetikai ikerkutatásokra ad lehetőséget.

\section{DISZKORDÁNS IKREK FONTOSSÁGA A POPULÁCIÓALAPÚ IKERREGISZTER LÉTREJÖTTÉBEN}

Közismert, hogy az egypetéjủ ikrek genetikai állománya csaknem 100\%-ban azonos, amit egy 2005-ben megjelent tudományos közlemény részben megcáfolt. Ugyanis miért van az, hogy egy egypetéjü ikerpár két tagja közül olykor csak az egyik iker betegszik meg szív-érrendszeri betegségben vagy daganatban? A legújabb ikervizsgálatok épp a különbözö krónikus betegségben szenvedő egypetéjü ikreket célozzák meg, hiszen így azonosítható, hogy mely génszakasz hibája s milyen életmódbeli tényezők vezettek a betegség kialakulásához. Ilyen, ún. diszkordáns ikerpárokat - különösen, ha egy ritka betegségröl van szó - olykor nemcsak ország-, hanem világszerte is nehéz találni, azonban egy olyan országban, mely rendelkezik populációalapú ikerregiszterrel, felkutatásuk akadályai elhárulnak, és így a tudomány számára rendkívüli lehetőséggel szolgálnak. Ezen populációalapú ikerregiszterek ritkák, a világ ikerregisztereinek mindössze kb. 5-10\%-át 
képezik. E ritkaság oka, hogy felépítésükhöz szükség van az illető ország csaknem összes ikerpárjának adatfelvételére, ennek megvalósítása kevés országnak áll módjában. Több évnyi előkészítő munkát követően, 2019-ben megalakul a populációs alapú Magyar Ikerregiszter a Semmelweis Egyetemen, melynek során az ország összes ikerpárját (közel 98500 felnőtt, és a tizennyolc év alattiakkal együtt 120 ezer körüli iker) megkeressük, és felkérjük öket az ikerregiszterbe való belépésre. Több tízezer fös ikerregiszter alakulhat meg hazánkban, mellyel a világ tíz legnagyobb ikerregiszterének egyike lehetünk. Ilyen diszkordáns egypetéjü ikrek vizsgálata csak akkor lehetséges, ha az ikerregiszternek elegendően nagy mintája van ahhoz, hogy ilyen ikerpárokat találjon. A fenotípusbeli különbségek vizsgálatára különböző képalkotó módszerek állnak rendelkezésre.

\section{KÉPALKOTÁS SZEREPE AZ IKERVIZSGÁLATOKBAN}

A képalkotó technológia az elmúlt évtizedben robbanásszerü fejlődést mutat, az újabb képalkotó módszerek megjelenése mellett a tradicionális technikák - főként az ultrahang, MR, illetve a CT, beleértve a nukleáris medicina tárházát is - kifinomultabbak, részletgazdagabbak lettek, melyek segítségével a radiológiai fenotípusok átfogóbb vizsgálatára van lehetőség. Hogyan segíthet ebben az ikerkutatás, vagy fordítva: hogyan segíthetnek a képalkotó módszerek az ikerkutatásban?

A radiológiai módszereket az utóbbi évtizedekben egyre gyakrabban használták a képalkotó fenotípusok kialakulása hátterében szerepet játszó genetikai tényezők szerepének vizsgálatára. Az első radiológiai vonatkozású ikervizsgálatok esetbemutatásokon alapultak. Egy skót esettanulmány egy recidív jobb könyök diszlokációban szenvedő egypetéjű ikerpárról számolt be, mely felvetette az esetleges örökletes hátteret (Fazzi-Rymaszewski, 1996). Egy másik publikáció egy egypetéjú japán ikerpár mindkét tagjánál egyszerre kialakult, CT-vel igazolt externális hidrokefaluszt írt le. Az ikrek a terápiára azonos módon reagáltak (Wachi-Sato, 1997). Vajon a közös genetikai háttér befolyásolta mindezen eltérések kialakulását az ikerpár mindkét tagjában? Az esetbemutatásokból természetesen általános következtetést nem lehet levonni, de felhívhatják a figyelmet arra, hogy nagyobb esetszámú ikervizsgálat keretén belül érdemes a genetikai hátteret tovább kutatni. A betegség képi megjelenésében rejlő hasonlóságokat az ikerpárok tagjai között radiológiai módszerekkel lehet látványosan bemutatni.

Az utóbbi évtizedek ún. klasszikus ikervizsgálatai, melyek egy- és kétpetéjü ikerpárokat vonnak be, a betegség hátterében álló varianciát három komponensre bontják: additív vagy domináns genetikai (A/D), közös (C) és egyéni (E) környezeti tényezőkre. A vizsgálatok során képalkotó módszerek segítségével állapították meg a betegség jelenlétét, annak mértékét, súlyosságát, illetve élettani, patofiziológiai jellemzőit. Példaként elsőként az angol ikerregiszter vizsgálatát idézzük, 
ahol a csípőízületi kopást vizsgálták ikrekben. Retrospektív módon visszakeresték az ikreknél elkészült csípő röntgenfelvételeket, és a csípöízületi rés szükületét és az acetabulum anatómiáját hasonlították össze, melynek során erős örökletességet állapítottak meg (Antoniades et al., 2001). Koreai és ausztrál ikerkutatók a mammográfia során mérhető emlődenzitás örökletességét vizsgálták, $\mathrm{s}$ arra voltak kíváncsiak, hogy találnak-e összefüggést az emlörák kialakulásával. Az emlődenzitás kialakulását $63 \%$-ban befolyásolták a genetikai faktorok, $\mathrm{s}$ a mammográfiai felvételeken gyakran megfigyelhető kompaktabb, denz emlöállomány esetén az emlőrák kockázata 1,8-6-szor magasabbnak mutatkozott, mint akiknek kevésbé vagy egyáltalán nem denz az emlőjük (Boyd et al., 2002). Mesterséges intelligencia módszerek segítségével a denz emlőkön belüli denz és nem denz területek kiterjedésének örökletességét külön elemezték. A szerzők azt találták, hogy ugyanazon genetikai faktorok befolyásolják mindegyik paramétert, de különböző módon, s közöttük magas genetikai kovariancia áll fenn (Stone et al., 2006).

Az ikerkutatások során prospektív CT-vizsgálattal kevéssé találkozunk, mivel azok sugárterheléssel járnak, így a CT-vel kapcsolatos ikervizsgálatok többsége retrospektív jellegủ. Példaként egy thaiföldi kutatás ikrek orrmelléküreg CT-vizsgálatait elemezte. Az orrmelléküreg anatómiájának örökletességét illetöen nem találtak lényeges különbségeket az egy- és kétpetéjü ikrek között: a paranazális szinuszok kifejlődése sokkal inkább a környezeti faktorok függvényének bizonyult (Chaiyasate et al., 2007). Saját, magyar munkacsoportunk 105 egy- és kétpetéjű ikerpár szív CT-vizsgálatát végezte el a városmajori Szív- és Érgyógyászati Klinikán Dr. Maurovich-Horvat Pál vezetésével, ahol a koronária anatómia sem mutatkozott tökéletesen egyformának az egypetéjü ikerpárok tagjai között. A koronáriák kanyargósságát, lefutását modellezéssel próbáljuk pontosan megállapítani és összehasonlítani az ikrek között. A meszes típusú plakkok jelenléte és kiterjedése (calcium scoring) nagyobb hasonlóságot mutatott az egypetéjű ikerpárok között, mint a kétpetéjü ikrek esetén, additív genetikai meghatározottságra utalva, míg a kardiovaszkuláris szempontból magasabb rizikót jelentő lágy, koleszterindús plakkok inkább a környezet által meghatározottak.

A sugárterheléssel nem járó ultrahangvizsgálatokat számos területen alkalmazzák az ikerkutatásban (1. és 2. a, b ábra), a policisztás ovárium szindrómától kezdve a szaruhártya megítélésén át az érelmeszesedés vizsgálatáig széleskörüen alkalmazott módszer. Néhány ultrahangos ikervizsgálatot emelnénk ki ezek közül. A finn ikerregiszter hüvelyi ultrahang vizsgálattal ítélte meg a méh gyakori jóindulatú daganata, a mióma előfordulását. A miómák száma gyenge genetikai meghatározottságot igazolt, míg a miómák előfordulása összefüggést mutatott a magasabb testsúly-testmagasság indexszel (Luoto et al., 2000). A fejlődő országokban egyre gyakrabban előforduló epekövesség molekuláris patogenezise nem teljesen ismert. A svéd ikerregiszter munkatársai epekövességben szenvedő ikerpárok - részben ultrahangos - vizsgálata során kimutatták, hogy az 
ABCG8 D19H génvariánst hordozó egyéneknek nagyobb az epekövességre való hajlamuk (Katsika et al., 2010). A hazánkban is minden negyedik felnőttet érintő nem alkoholos zsírmáj hátterében additív genetikai hátteret nem igazolt vizsgálatunk, közös $(74,2 \%)$ és egyéni $(25,8 \%)$ környezeti tényezők állnak a betegség hátterében (Tárnoki et al., 2012). Szintén hazai ikermintánkon ultrahanggal vizsgáltuk a veseparenchima vastagságában szerepet játszó genetikai meghatározottság mértékét, mely korra és nemre korrigálva $0 \%$-os volt, a közös (30\%) és egyéni (70\%) környezeti tényezők hatásai domináltak. Eredményeink az életmód, illetve a primer prevenció fontosságára hívták fel a figyelmet (Tárnoki et al., 2013).

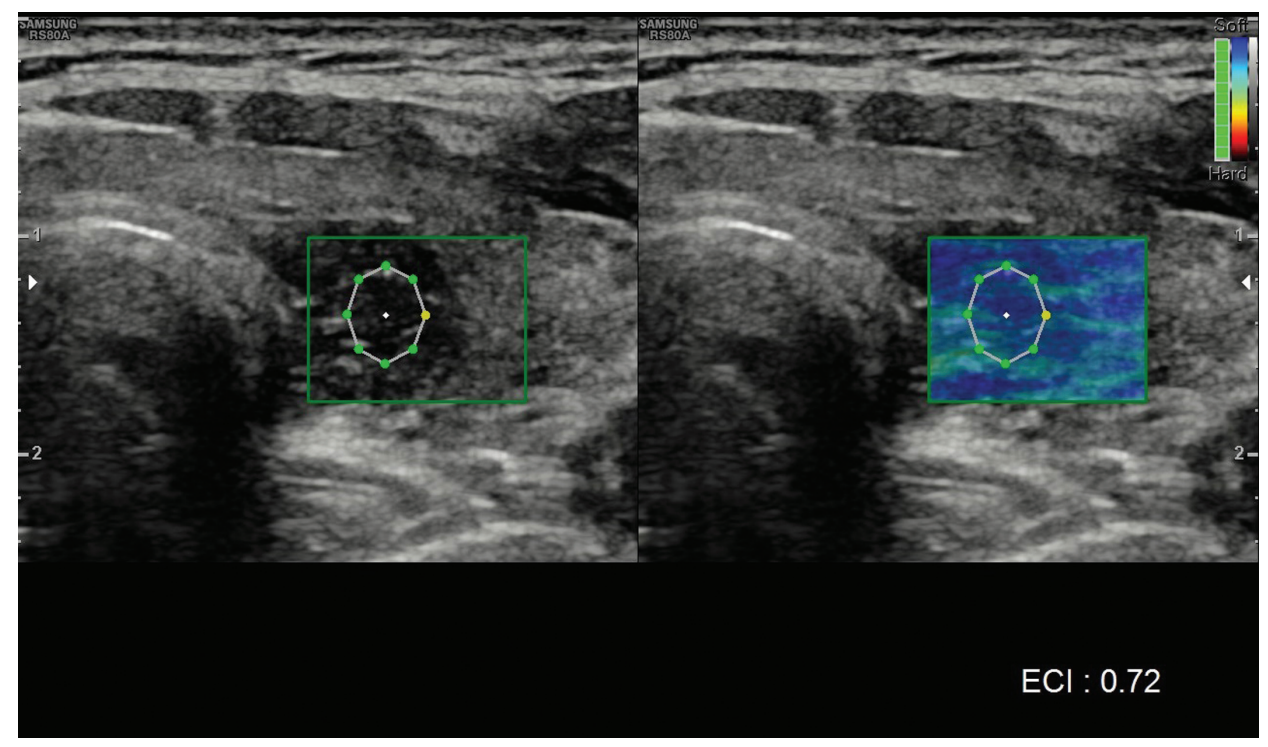

1. ábra. Magyar ikeralany pajzsmirigy ultrahang elasztográfiás mérése, melynek során a göbök elaszticitási indexét vizsgáltuk

Az ionizáló sugárzással nem járó magnetikus rezonancia (MR) vizsgálat szintén közkedvelt képalkotó eljárás prospektív ikervizsgálatok esetén (3. $a, b$ ábra). Számos területen, föleg a neuroradiológiában alkalmazzák ikrekben. Egyik MR kutatási terület a diffúziós tenzor képalkotás (DTI), melynek során azt vizsgálják, milyen mértékben befolyásolják a genetikai tényezők az agyi kapcsolatokat különböző agyi területeken. A DTI-rekonstrukcióból származó frakcionált anizotrópia tizenegy nagy fehérállományi pálya esetében nagyon örökletesnek bizonyult (Kochunov et al., 2015). Az MR-vizsgálat a T1-szekvencián magas jelintenzitást mutató zsírréteg megítélésére is kiválóan alkalmas. Ezt használták ki egy ausztrál ikervizsgálat során, ahol MR segítségével kapcsolatot mutattak ki az alacsony születési súly és az emelkedett zsigeri, illetve szubkután zsírszövet térfoga- 

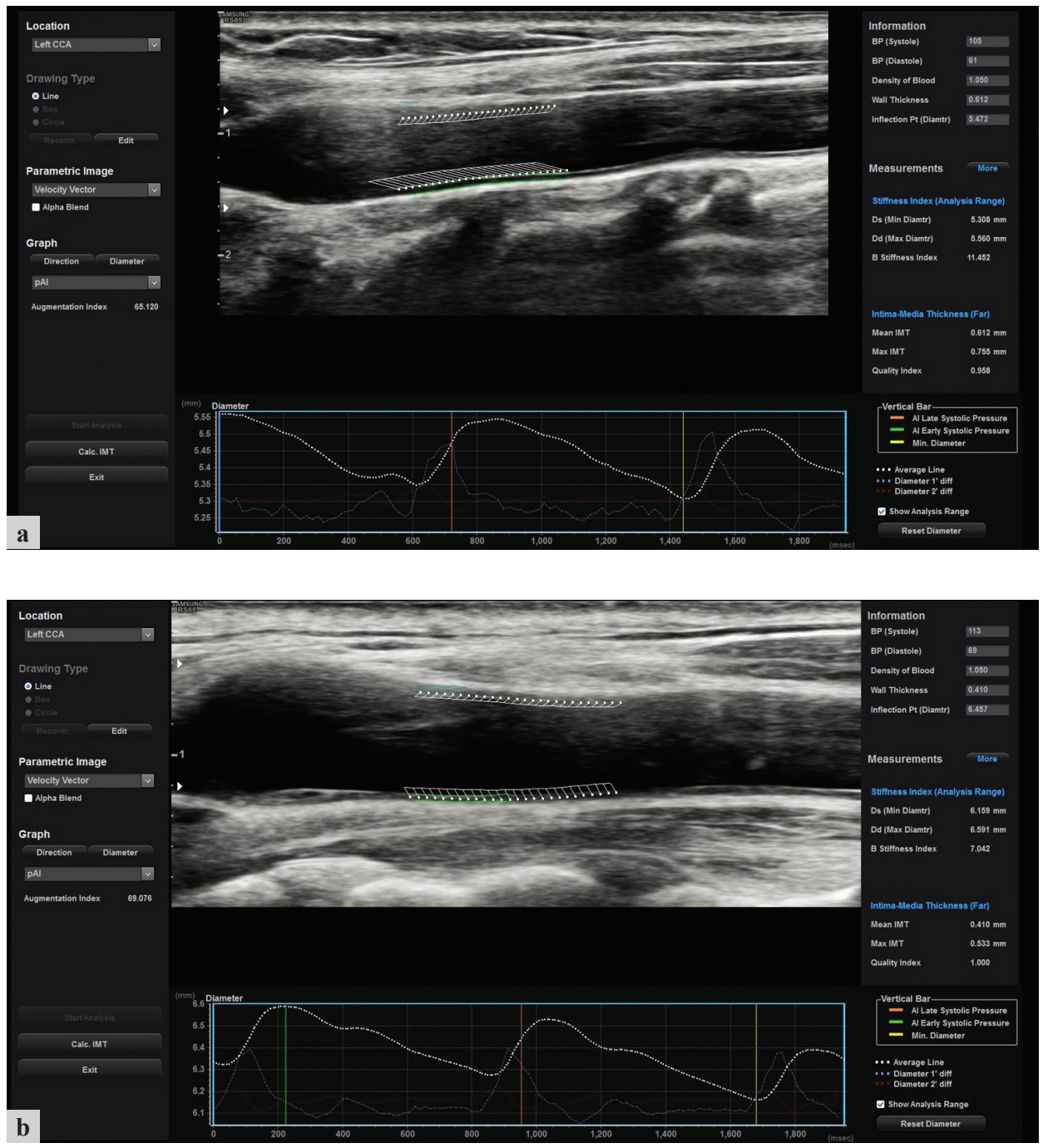

2. a, b ábra. Egypetéjü magyar ikerpár két tagjának (A: elsőszülött, B: másodszülött) arteria carotis communis automatikus IMT mérése (disztális falon avektorral jelölt terület alatt), illetve localis stiffness mérése

ta között, ami azt jelenti, hogy zsigeri és hasi elhízásra nagy kockázatot jelent az alacsony születési súly (Hng et al., 2006), mely összhangban van az epigenetikai tanulmányok eredményeivel, hiszen ez a várandósság alatti kóros programozódást tükrözi. A finn ikerkutatók obezitás-diszkordáns egypetéjü ikerpárokon végeznek vizsgálatokat. Olyan egypetéjü ikerpárokban, akik hosszú távon a fizikai aktivitásban különböznek, MR-vizsgálattal kimutatták, hogy a rendszeres fizikai 

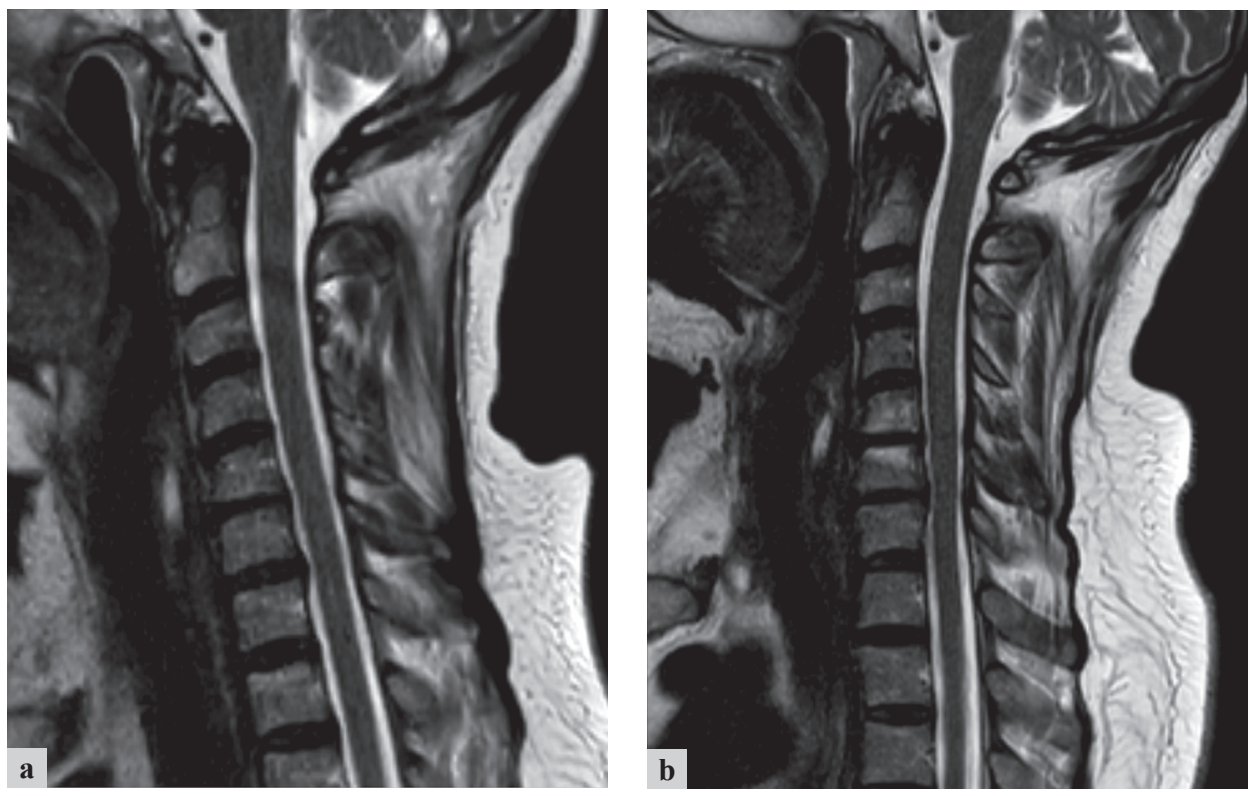

3. a, b ábra. Egy 64 éves egypetéjü magyar ikerpár két tagjának (A: elsőszülött, B: másodszülött) nyaki gerinc MR-vizsgálata (T2-szekvencia), melyek hasonló mértékủ degeneratív eltéréseket mutatnak

aktivitás fontos tényezőnek számít a magas rizikójú zsírszövetek lerakódásának megelőzésére, még akkor is, ha a genetikai meghatározottság és a gyermekkori környezeti tényezők állnak a legtöbb antropometriai paraméter, például a testzsír, BMI, testsúly stb. hátterében (Leskinen et al., 2009). Ezt igazolja a fizikai aktivitás által kiváltott epigenetikai módosulás, a hisztonkód átrendeződés, valamint a PGC-1 $\alpha$ génmetiláció dózisfüggő csökkenése. A magas rizikójú zsírszövet felszaporodásának adverz hatásait egy fizikai aktivitásra diszkordáns egypetéjü férfi ikerpáron mutatták be. Azonos foglalkozásuk mellett az aktívabb iker rendszeresen futott, míg inaktív ikertestvére ülő helyzetben töltötte legtöbb idejét, így MRrel igazolva 74\%-kal több viscerális, 150\%-kal magasabb az intramuszkuláris és 63\%-kal magasabb szubkután zsírszövettel rendelkezett, s szintén összefüggést találtak a máj és a pankreász zsírtartalma, illetve az inzulinrezisztencia között (Hannukainen et al., 2011).

A csaknem azonos genetikai állományú egypetéjü ikrek vizsgálata tehát - ha egyikőjük krónikus betegségben szenved - segíthet megérteni, hogy a gének és a környezet hogyan járulnak hozzá a komplex betegségek kialakulásához és radiológiai megjelenésükhöz. Az epigenetikai markereken felül a bélbaktérium-flóra összetétele is befolyásolhatja a betegségek kialakulását, akár esetleg radiológiai megjelenését is. 


\section{MIKROBIOM}

A belekben számos mikroba (mikrobiota) található (egy egészséges egyénben mikrobák trilliói fordulnak elö), melyek a metabolizmusban fontos szerepet játszanak. Összetételük és diverzitásuk egyénenként változó. A legelső bélmikrobiommal kapcsolatos ikervizsgálat kimutatta, hogy a bélrendszerben lévő baktériumflóra a családtagok között nagyon hasonló, s összefügg az obezitással is (Turnbaugh et al., 2009). A későbbi évek során kiderült, hogy az obezitáson kívül számos más környezeti tényező befolyásolja a mikrobiom összetételét (Cresci-Bawden, 2015), illetve különféle betegségek kialakulásával áll összefüggésben. Az angol ikerregiszter 416 ikerpártól több mint ezer székletmintát gyüjtött össze, s számos mikrobiális taxont azonosítottak, amelyek közül a legjobban öröklődő a Christensenellaceae volt, ezen baktérium mennyisége az alacsony BMI-vel rendelkező egyéneknél nagyobb számban fordult elő (Goodrich et al., 2014). A mikrobiommal kapcsolatos ikervizsgálatok száma nő, s egyre több betegséggel kapcsolatos összefüggést igazolnak krónikusbetegség-diszkordáns egypetéjü ikerpárok segítségével. A mikrobiom-diszkordáns egypetéjü ikrek különböző radiológiai megjelenése példát mutathat arra, hogy a különböző bélbaktérium-flórák milyen fenotípusbeli különbségeket okozhatnak, melyek később, a diagnosztika során új biomarkerként szolgálhatnak. A bélbaktériumok által okozott bélgyulladás PET-MR-rel is kimutatható, s a probiotikumok segítségével „helyreálló” bélbaktérium-flórának köszönhetően csökkenő gyulladás mértéke követhető a képalkotás segítségével.

\section{RADIOGENOMIKA}

A radiológiai és patológiai tudományok az utóbbi évtizedekben szorosan egymás mellett fejlődtek, s kialakult a radiogenomika (vagy képalkotó genomika), mely a radiológiai és szövettani jellemzők közötti összefüggéseket vizsgálja. A két tudományterület ötvözésével új irányok nyíltak a daganatkutatásokban: radiológiai megjelenésbeli jellemzőket, úgynevezett „,radiológiai fenotípusokat” határozhatunk meg, melyek neminvazív módszerrel szerzett információt szolgáltathatnak a jövőben a génexpressziós mintázatokról, tumor esetén azok szubtípusairól és akár a molekuláris biológiai eltéréseiröl is. A microarray elterjedésével a génaktivitásbeli változások követésére, kromoszóma-rendellenességek feltárására és epigenetikai vizsgálatok elvégzésére is lehetőség van. Ezen neminvazív, rutin klinikai vizsgálatok segítségével már előre jelezhető lehet a kemoterápiás szerekre várható válasz, mely az optimális kezelés kiválasztásában segítve a klinikusoknak is iránymutató lehet (Rutman-Kuo, 2009). A génexpressziós mintázatok (gének több tucatja vagy százai) megismerése jelentősen segítheti a 
daganatok diagnosztikus besorolását, a prognózisbecslést és a kezelésekre adott terápiás válasz megítélését.

Számos daganat, például emlö-, tüdőrák, agyi daganatok (főként glioblasztóma) esetén igazolták a radiogenomika hatékonyságát. Példaként, glioblasztómában a periositin gén nagy mennyiségü termelődése (upregulation) összefüggésbe hozható a tumor volumenével MR FLAIR-szekvencián (Zinn et al., 2011). Emlőtumorban összefüggést találtak a heterogén kontrasztanyag halmozási mintázat és az interferon altípusú emlődaganatok között. Általánosságban elmondható, hogy a radiogenomikai kutatások manuális vagy szemiautomatikus módszereket használnak a radiológiai mintázatok mérésében, s azokat összefüggésbe hozzák génexpressziós egyéni mintázatokkal, illetve egyéb molekuláris fenotípusokkal. Így a biopszia előtt akár a radiológiai mintázatból következtethetünk a daganat típusára. A diszkordáns ikreken való radiológiai kutatások is a radiogenomikához csatlakoznak, hiszen a radiomorfológia segítségével lehet következtetni a betegség háttérében álló genetikai és epigenetikai mintázatra. Mindehhez szükséges, hogy a képalkotás során nyert, olykor jelentős mennyiségü információt precízen tudjuk elemezni és feldolgozni. Ebben a radiológus segítségére állhat a mesterséges intelligencia vagy gépi tanulás.

\section{MESTERSÉGES INTELLIGENCIA}

A radiológia területén az utóbbi években egyre nagyobb teret hódít a számítógép segítette diagnózis (computer-aided diagnosis, CAD), mely napjainkban több modalitás esetén (például mammográfia, olykor tüdőgócok) már a rutin klinikai munka részévé vagy segítségévé vált. A CAD a radiológust segítve másodvéleményt ad, ezáltal a diagnózis pontosabb lehet. Egy számítógépes algoritmusról van szó, melynek első lépése a képfeldolgozás, ezt követően a képelemzés és az adatok osztályozása mesterséges neurális hálózatok használatával (Shiraishi et al., 2011). Az egyre növekvő adatmennyiség, a big data és mesterséges intelligencia kombinációjával a radiológia és a patológia igen nagy fejlődésen esik át, s a jövőben a mesterséges intelligencia egyre inkább a rutin klinikai munka részesévé fog válni. Ennek során a mesterséges neurális hálózatokat finomítják mélytanulással (deep learning), amely nemcsak az eltérést ismeri fel, hanem azt ki is emeli a radiológus számára. A mélytanulás tehát - egy radiológus rezidenshez hasonlóan - egyre több eltérés láttán, azokon „okulva” finomít az eltérések felismerésén, autodidakta módon. Első körben mellkasröntgen felvételeken használták ki a mesterséges intelligencia által nyújtott lehetőségeket, manapság már a mammográfia, CT- és MR-vizsgálatok során is alkalmazzák. Elsősorban az emberi szem által igen nehezen (vagy akár nem) felismerhető finom eltérések észrevételében igen hasznos. Egyszerübb eltérések felismerésében és differenciálásában is alkalmazható, például tüdőtumor-keresés a szürő mellkas CT-n (Jha-Topol, 2016). A mesterséges 
intelligenciát már használják emlőtumorszürésre a mammográfián, illetve pulmonális embólia felismerésére mellkasi CT angiográfiás vizsgálatokon, valamint vizsgálatok folynak egyéb területen történő alkalmazásra. A mesterséges intelligencia az ikerkutatások során is hasznos segítséget nyújthat a képelemzésben.

\section{KÉPALKOTÓ EPIGENETIKA}

Az utóbbi évtizedben az epigenetika területén végzett kutatások új meglátást hoztak a biológia csaknem minden területén, mint például a sejtdifferenciáció, -növekedés, -fejlődés és a sejtöregedés. A képalkotás és az epigenetika kombinációja képes arra, hogy megválaszolja azokat a kérdéseket, hogy a különböző képalkotó fenotípusok elörejelezhetik-e az epigenetikai módosításokat, amelyek összefüggnek a szervek (például az agy) szerkezetével, müködésével és anyagcseréjével, ami befolyásolja a betegség kockázatát és progresszióját. A képalkotó módszerek epigenetikai markerekkel való integrálása, avagy a képalkotó epigenetika ígéretesnek tünik, különösen a neuroradiológia terén. Az egyik legfontosabb előrelépés a képalkotó epigenetikai vizsgálatok terén a kromatint módosító enzimek múködésének és funkcióinak kimutatása egyes agyi betegségek, például Alzheimer-kór esetén PET-MR-vizsgálattal (Wang et al., 2014). Az agyban kétféleképpen lehet epigenetikai tényezőket (mint például az epigenetikai enzimaktivitásból származó fehérje vagy nukleinsav módosulása) kimutatni: közvetlen vagy funkcionális/ közvetett megfigyeléssel. A közvetlen megfigyelés részletes információt nyújt magáról az epigenetikai markerről: egy epigenetikai enzimműködés termékeként létrejövő fehérjéről vagy nukleinsavról (egy specifikus, szűk kötődésủ ligand segítségével). A funkcionális megfigyelések alkalmazásával azonban vizualizálható lehet egy fehérje vagy enzim hatása az agymüködésre. Eddigi vizsgálatok bizonyították, hogy a kromatinmódosító enzimek kulcsfontosságú szerepet játszanak a transzkripciós változásokban. Több betegséget hoztak már ezzel összefüggésbe, köztük neurodegeneratív rendellenességeket, skizofréniát, depressziót és az addikciót is. Ezen új, cerebrális betegségekben kromatinmódosulásokat vizsgáló, PETMR-rel kombinált módszer a közeljövőben akár szerepet játszhat a kezelésre adott válasz monitorozásában, illetve a gyógyszerfejlesztésekben is.

\section{A JÖVŐ KÉPALKOTÓ IKERVIZSGÁLATAI}

A genetikai, epigenetikai és a mikrobiom adatok képalkotással való kombinálása a sejtbiológiai, patológiai jellemzők radiológiai megjelenítését jelenti. A genetikai, környezeti és az epigenetikai tényezők, továbbá a mikrobiom összjátéka által „kialakuló” fenotípus leképezésére legalkalmasabb, nem sugárterhelő képalkotó 
módszer az ultrahang és az MR-vizsgálat. A klasszikus ikervizsgálaton túl a krónikus betegségben szenvedő diszkordáns egypetéjü ikrek megfelelö metodikai modellként segíthetnek megérteni ezen összefüggéseket. A radiogenomikai precíz elemzést a mesterséges intelligencia teheti hatékonyabbá.

\section{IRODALOM}

Antoniades, L. et al. (2001): The Genetic Contribution to Hip Joint Morphometry and Relationship to Hip Cartilage Thickness. Osteoarthritis and Cartilage, 9, 6, 593-595. DOI: 10.1053/ joca.2001.0426, https://www.oarsijournal.com/article/S1063-4584(01)90426-1/pdf

Boyd, N. F. et al. (2002): Heritability of Mammographic Density, a Risk Factor for Breast Cancer. The New England Journal of Medicine, 347, 12, 886-894. DOI: 10.1056/NEJMoa013390, https://www.nejm.org/doi/full/10.1056/NEJMoa013390

Chaiyasate, S. et al. (2007): Analysis of Paranasal Sinus Development and Anatomical Variations: A CT Genetic Study in Twins. Clinical Otolaryngology, 32, 2, 93-97. DOI: 10.1111/j.13652273.2007.01404.x

Cresci, G. A. - Bawden, E. (2015): Gut Microbiome: What We Do and Don't Know. Nutrition Clin Pract, 30, 6, 734-46. DOI: 10.1177/0884533615609899, https://www.ncbi.nlm.nih.gov/pmc/articles/PMC4838018/

Fazzi, U. G. - Rymaszewski, L. A. (1996): Recurrent Dislocation of the Elbow in Identical Twins. Journal of Shoulder and Elbow Surgery, 5, 5, 401-403. DOI: 10.1016/S1058-2746(96)80072-3

Goodrich, J. K. et al. (2014): Human Genetics Shape the Gut Microbiome. Cell, 159, 4, 789-799. DOI: 10.1016/j.cell.2014.09.053, https://bit.ly/2WisUN8

Hannukainen, J. C. et al. (2011): Liver and Pancreatic Fat Content and Metabolism in Healthy Monozygotic Twins with Discordant Physical Activity. Journal of Hepatology, 54, 3, 545-552. DOI: $10.1016 /$ j.jhep.2010.07.029, https://www.academia.edu/16385696/Liver_and_pancreatic_ fat_content_and_metabolism_in_healthy_monozygotic_twins_with_discordant_physical_activity

Hng, T. M. et al. (2006): The Interrelation of Birth Weight and Regional Lipid Deposition: A Twins Study. Metabolism, 55, 5, 561-562. DOI: 10.1016/j.metabol.2006.01.007

Jha, S. - Topol, E. J. (2016): Adapting to Artificial Intelligence: Radiologists and Pathologists as Information Specialists. Journal of the American Medical Association, 316, 22, 2353-2354. DOI:10.1001/jama.2016.17438, https:/www.researchgate.net/publication/311164171_Adapting_ to_Artificial_Intelligence_Radiologists_and_Pathologists_as_Information_Specialists

Katsika, D. et al. (2010): Gallstone Disease in Swedish Twins: Risk Is Associated with ABCG8 D19H Genotype. Journal of Internal Medicine, 268, 3, 279-285. DOI: 10.1111/j.13652796.2010.02249.x, https://onlinelibrary.wiley.com/doi/full/10.1111/j.1365-2796.2010.02249.x

Kochunov, P. et al. (2015): Heritability of Fractional Anisotropy in Human White Matter: A Comparison of Human Connectome Project and ENIGMA-DTI Data. Neuroimage, 111, 300-311. DOI: 10.1016/j.neuroimage.2015.02.050, https:/www.ncbi.nlm.nih.gov/pmc/articles/ PMC4387079/

Leskinen, T. et al. (2009): Leisure-Time Physical Activity and High-Risk Fat: A Longitudinal Population-Based Twin Study. International Journal of Obesity (London), 33, 11, 1211-1218. DOI: 10.1038/ijo.2009.170, https://www.nature.com/articles/ijo2009170

Luoto, R. et al. (2000): Heritability and Risk Factors of Uterine Fibroids. The Finnish Twin Cohort Study. Maturitas, 37, 1, 15-26. DOI: 10.1016/S0378-5122(00)00160-2 
Rutman, A. M. - Kuo, M. D. (2009): Radiogenomics: Creating a Link between Molecular Diagnostics and Diagnostic Imaging. European Journal of Radiology, 70, 2, 232-241. DOI: 10.1016/j. ejrad.2009.01.050, https://www.researchgate.net/publication/24216847_Radiogenomics_Creating_a_link_between_molecular_diagnostics_and_diagnostic_imaging

Shiraishi, J. et al. (2011): Computer-aided Diagnosis and Artificial Intelligence in Clinical Imaging. Seminars in Nuclear Medicine, 41, 6, 449-462. DOI: 10.1053/j.semnuclmed.2011.06.004, https://www.researchgate.net/publication/51705200_Computer-Aided_Diagnosis_and_Artificial_Intelligence_in_Clinical_Imaging

Stone, J. et al. (2006): The Heritability of Mammographically Dense and Nondense Breast Tissue. Cancer Epidemiology, Biomarkers \& Prevention, 15, 4, 612-617. DOI: 10.1158/1055-9965.EPI05-0127, http://cebp.aacrjournals.org/content/15/4/612.long

Tárnoki A. D. et al. (2012): Heritability of Non-Alcoholic Fatty Liver Disease and Association with Abnormal Vascular Parameters: A Twin Study. Liver Int, 32, 8, 1287-1293. DOI: 10.1111/j.14783231.2012.02823.x, https://lib.semmelweis.hu/sepub/pdf/2012/a22651705

Tárnoki D. L. et al. (2013): Genetic and Environmental Variance of Renal Parenchymal Thickness: A Twin Study. Croatian Medical Journal, 54, 6, 550-554. DOI: 10.3325/cmj.2013.54.550, https://www.ncbi.nlm.nih.gov/pmc/articles/PMC3914463/

Turnbaugh, P. J. et al. (2009): A Core Gut Microbiome in Obese and Lean Twins. Nature, 457, 7228, 480-484. DOI: 10.1038/nature07540, https:/www.ncbi.nlm.nih.gov/pmc/articles/ PMC2677729/

Wachi, A. - Sato, K. (1997): Anatomical and Biomechanical Similarity in Intracranial Environment in Identical Twins with External Hydrocephalus. Child's Nervous System, 13, 11-12, 633-635. DOI: $10.1007 / \mathrm{s} 003810050158$

Wang, C. et al. (2014): Visualizing Epigenetics: Current Advances and Advantages in HDAC PET Imaging Techniques. Neuroscience, 264, 186-197. DOI: 10.1016/j.neuroscience.2013.09.018, https://www.ncbi.nlm.nih.gov/pmc/articles/PMC3956707/

Zhai, G. et al. (2007): Genetic Influence on the Progression of Radiographic Knee Osteoarthritis: A Longitudinal Twin Study. Osteoarthritis Cartilage, 15, 2, 222-225. DOI: 10.1016/j. joca.2006.09.004, https://www.oarsijournal.com/article/S1063-4584(06)00269-X/fulltext

Zinn, P. O. et al. (2011): Radiogenomic Mapping of Edema/Cellular Invasion MRI-Phenotypes in Glioblastoma Multiforme. PLOS One, 6: Pp. E25451 DOI:10.1371/annotation/b5267cb36aa7-47fc-a648-47f30a7cff3e, https://journals.plos.org/plosone/article?id=10.1371/journal.pone. 0025451 